Proceedings

Juntendo Medical Journal

2016. 62 (Suppl 1), 18-21

\title{
It Is Time to Implement the Sportology Towards the 2020 Games and Beyond
}

\author{
MASATO MIZUNO* \\ *Former CEO Tokyo 2020 Bid Committee \\ In order to establish healthy society as legacy of 2020 Games, the Sportology must be promoted and implement \\ concrete actions.
}

Key words: aged society, healthy society, Tokyo 2020 Games, tangible legacies, intangible legacies

\section{Preface}

The concept of the Sportology is the study on Sports through the sciences that contains natural science, social science and culture science, in order to establish a healthy society through Sports. It is time to implement concrete measures to realise a healthy society through Sportology during the preparation phase towards Tokyo 2020 Games and beyond.

The context of this lecture would be the three Es, economy, epidemics and environment which threatens human-beings, the significance of hosting the Olympic and Paralympic Games in 2020, the elements of the bid activities and the importance of the Olympic Legacies which Sportology should be implemented as one of the factors to establish a healthy society.

\section{The existing state of the world}

The three Es which are the economy of the world, epidemics and environment are supposed to threaten human-beings. Very severe economic situation in China, Middle East, Russia and the European Union shows that it is quite critical that it could threaten the livelihood of the world. Epidemics such as Ebola fever, MERS, Dengue fever and especially bird flu are thought to be very dangerous that its virus might be evolved having infectious human to human in the future.

Environment is another key $\mathrm{E}$ that endangers human-beings. The climate change caused by the global warming creates extreme temperature changes, floods, draughts, storms and shift in producing area of agricultural products. In this uncertain period around the world, Japan should become a role model at the occasion of the Tokyo 2020 Olympic and Paralympic and leave excellent legacy for the future.

\section{The significance of hosting the Games}

There are two important meanings to host the Games. Needless to say, the first meaning is to deliver the games safely, smoothly, while celebrating world peace, excitement, Olympic Movement and encouraging the people around the world.

The other meaning is to leave tangible and intangible legacies beyond 2020 to help establish a healthy society. Every Olympic legacies are evaluated ten years after the Games to see if the legacies were left effectively to help establish a better society in long term.

\section{The bid activities}

The vision of the bid period was that Tokyo 2020 will bring together dynamic innovation and global inspiration. It will unite the power of the Games

Masato Mizuno

Mizuno Corporation

3-22 Kanda-Ogawa-Machi, Chiyoda-ku, Tokyo 101-0052, Japan

TEL: +81-3-3233-7001

The $2^{\text {nd }}$ Congress, International Academy of Sportology 〔Held on Sep. 12, 2015]

[Received Dec. 1, 2015] 
with the unique values of the Japanese people and the excitement of a city that sets global trends. It will be a unique celebration that will help reinforce and renew the Olympic Values for the new generation. And will contribute to more young people worldwide, sharing the dreams, hopes and benefits of sport.

The new Games vision and the concept of the Games were announced by the Organizing Committee. "Sports has a power to change the world and our future. The Tokyo 1964 Games completely transformed Japan. The Tokyo 2020 Games, as the most innovative in history, will bring positive reform to the world by building on three core concept; Striving for your personal best (Achieving personal best), Accepting one another (unity in diversity), Passing on legacy for the future (connecting to tomorrow)"

The Tokyo 2020 Bid Committee was formed on $7^{\text {th }}$ of Sept. 2011 and the bid activities started officially after all the preparation work had done by the 2020 Bid Strategy Division of Japanese Olympic Committee (JOC) since Nov. 2009 after the 2016 bid defeated by Rio de Janeiro.

The Committee worked with strong team work along the road map until the voting day, essential six bid activities are categorized as follows:

\section{Fund raising}

Taking the advice from the International Olympic Committee (IOC) that the bidding budget should be small, the budget of the 2020 Bid was US\$ 75 mil (in case US $\$ 1.00=\backslash 100^{-}$) which was half of the 2016 bid budget. About half of the budget which was $\$ 37$ million was provided by the Tokyo Metropolitan Government (TMG) and the rest, which was 38 mil was raised by the private sector. One difficulty was that the Bid Committee carried over the deficit of 2016 bid which was $\$ 7.5$ million. Therefore, the Committee had to raise over $\$ 45.5$ million in total. Fortunately, after the winning of the Liberal Democratic Party (LDP) at the general election of Japan in the end of 2012, the fund raising went quite smoothly reaching the target.

\section{Planning}

Planning team made up excellent comprehensive plan to host the Olympic and Paralympic Games in 2020. There were 14 themes according to the IOC request as follows;

(1) Vision, legacy and communication

(2) Overall concept of the Olympic Games

(3) Political and public support

(4) Legal aspects

(5) Environment

(6) Finance

(7) Marketing

(8) Sport and venues

(9) Paralympic Games

(10) Olympic Village

(11) Games safety, security and medical services

(12) Accommodation

(13) Transport

(14) Media operations

The Candidature File, compiled all the themes which was published and distributed to the IOC and the IOC members, The International Federations and disclosed on the Tokyo Bid Web Site.

\section{Promoting the support rate}

The IOC evaluated the candidate cities by the passion of the citizens desiring to host the Games by a random survey. The first survey showed only $47 \%$. The Bid Committee worked very hard to raise the figures. Unique and powerful promotion was done by the promotion team and the PR team, $58 \%$ before London Games, 63\% after London Games, making all kinds of promotion such as Ginza Parade to celebrate the medalists which increased the rate to over $70 \%$ at the begging of the 2013. The media reports of the IOC Evaluation Commission Visit again raised the rate to $83 \%$ and the final stage in August the rate went up to $92 \%$ due to heavy media exposures.

\section{Best response to the IOC Evaluation Commission}

The three day evaluation was conducted in early March 2013 by the IOC Evaluation Commission of 15 members which consisted of IOC members, International Federations (IF) and National Olympic Committee (NOC) representatives and experts. There were presentations of the themes followed by question and answer session in the morning. After lunch, there was a venue sight visit by bus. Six months precise preparation was required to for this evaluation. Tokyo obtained very high evaluation in the IOC evaluation report which was published in the end of June 2013. 


\section{Presentation}

Every candidate city had equally four chance to make a presentation at international sports conferences in St. Petersburg, twice in Lausanne and a final presentation at the IOC Session in Buenos Aires. The Bid Committee made very careful preparations to set up appropriate themes, selection and appointment of speakers, effective personal training, and rehearsals for every occasions. The bid committee made efforts to convey the themes clearly using easy to understand vocabulary to reach every audiences. It was so nice that the presentation of Team Tokyo was highly evaluated.

\section{Lobbying}

One of the most important element is lobbying in order to obtain support from each IOC members who was eligible to vote at the host city selection. The bid leaders, president of JOC and CEO of the Bid Committee met, talked and tried their best to convince to obtain their support individually at every occasion. Building up friendship, mutual understanding and trust is indispensable for lobbying. At the same time, the Bid Committee was very careful not to infringe the regulations and rules on the bid activities.

\section{The Legacy}

As previously mentioned, there are two meanings for hosting the Olympic and Paralympic Games. Firstly, the Games must be delivered smoothly and safely with sharing excitement, movement, and encouragement as a role model on hosting Games. Secondly, the games must leave valuable legacies beyond 2020. There are tangible and intangible legacies.

\section{The tangible legacies}

a) The permanent sport facilities will be built for the Games, but those venues should not become white elephants. In order to create good legacies, all the facilities must be planned as multi-use and properly filled up with sport events, musical concert and conventions.

b) Barrier free installments

Paralympic Games must be also world showcase for the disabled athletes. The combination of the state of art technology, newly developed raw materials and creativity are expected to develop stunning systems to produce an ideal living for disabled people.

c) Sustainability facilities and so on

No need to build any more infrastructures in the city.

2. Intangible legacies must be left beyond 2020 continuously for building healthy society such as;

a) Culture

We must protect and develop Japanese traditional culture in the society and allow people to new creation of cultures through fusion of other culture.

b) Education

Adding creative thinking ability to the traditional learning and memorizing educational way of Japan. The society will keep developing new education for youth but all ages as well.

c) Sustainability

In order to establish sustainable society beyond 2020 as an intangible legacy, the society must work hard to raise awareness of the reality and the severe state of environment and implementation of all the measures we can.

d) International exchange

Japanese are so to say, not good to communicate with foreign people because of language barrier. In order to promote to activate international exchange would be education of foreign language especially English which is most common language people use to communicate internationally. And setting up more occasions of international exchange, promoting for students to study outside of the country, increasing number of exchange students from overseas.

e) Volunteerism

Tokyo 2020 Games is a great chance to establish an ideal principle of the volunteerism to assist to manage the mega event and local event or meetings as well. It is in the Japanese culture to help others without compensation. This volunteer mind makes better communication and mutual understanding amongst citizens. At the same time it is important to set up a clear volunteer management system for recruiting, selecting, allocating, job description and team work building.

\section{f) Tourism}

Tourism has been enhanced by Japanese Government as one of the leading industry in the past few 
years for welcoming as many visitors for the Tokyo 2020 Games. Clarifying and marketing of all the resources of tourism in each areas should attract tourist from all over the world. Tourist around the wolrd could enjoy Japanese hospitality "Omotenashi”.

g) New business

It is estimated that about $70 \%$ of young people will establish their own business. Due to longevity and decreasing birthrate, the society's demands will be diversified and different. In order to supply the new different demands, the society must create new business with combination of profession and new technology, health and sustainability beyond 2020 as the legacy.

\section{It is the time to implement Sportology for the future}

In the recent years, Japan has become one of the top longevity society with significant decrease in birthrate. Consequently, citizens have desired better physical and mental health, preventing dementia, happiness, rejoicing and having fun. In order to establish healthy society as legacy of 2020 Games, the Sportology must be promoted and implement concrete actions. 